\title{
The spatial organization of oil and gas investments in South America: an analysis based on communities
}

A organização espacial dos investimentos em petróleo e gás na América do Sul: uma análise baseada em comunidades

\begin{abstract}
The global economy is organized in value chains, spatially and functionally fragmented. Despite this dispersion, the administrative activities of these chains continue to be concentrated in some cities, which play an important role in certain chains, because they concentrate companies and economic flows. The research on value chains has not focused on the city level and has adopted mainly case studies as the methodological approach. Considering this, we apply a network methodology to analyse the powerful cities in the South American oil and gas investment network, including the attributes that explain this position and the spatial extent of it. To perform this analysis, we use data on green and brownfield investments. Our results indicate that Rio de Janeiro is the most central city in this network, but its action is mainly concentrated in Brazil. This work seeks to contribute mainly to the methodological development of the studies in the area.
\end{abstract}

\section{Keywords}

global value chains, networks, Louvain communities, oil and gas.

JEL Codes F21, F60, L71, L14.

\author{
Mariane Santos Françoso (1) \\ Moritz Breul (2) \\ Celio Hiratuka ${ }^{(3)}$ \\ (1) State University of Campinas \\ (2) University of Cologne \\ (3) State University of Campinas
}

\section{Resumo}

A economia global está organizada em cadeias de valor, fragmentadas espacial e funcionalmente. Apesar dessa dispersão, as atividades administrativas e de controle dessas cadeias continuam concentradas em algumas cidades, que detém um papel importante em certas cadeias, por concentrarem empresas e fluxos econômicos. A pesquisa nessa área não se concentrou no nível da cidade e adotou, mais comumente, estudos de caso como metodologia. Diante disso, este trabalho adotará a metodologia de rede para analisar o poder das cidades na rede de investimento em petróleo e gás da América do Sul, os atributos que explicam essa posição e a extensão espacial dela. Para realizar esta análise, serão usados dados sobre investimentos green e brownfield. Os resultados indicam que o Rio de Janeiro é a cidade mais central dessa rede, mas sua ação está concentrada principalmente no Brasil. Este trabalho pretende contribuir principalmente no desenvolvimento metodológico dos estudos na área.

\section{Palavras-chave}

cadeias de valor, redes, comunidades Louvain, petróleo e gás.

Códigos JEL F21, F60, L71, L14. 


\section{Introduction}

The organization of the global economy has undergone intensive changes since the 1970s. With the increase of capital mobility, production began to be organized into global value chains, that is, production began to occur in a fragmented and spatially dispersed way, with several companies and localities involved in the manufacturing process of a product (Gereffi, 2001; Gereffi, 2013).

Despite the spatial dispersion and the fact that manufacturing has moved away from large cities, these cities still concentrate a great part of the value chains' administrative activities, which implies a strong concentration of global economic flows in these cities, as they host multinationals' corporate offices, financial institutions, and service providers (Friedmann, 1986; Sassen, 1991).

As a result, some cities play an important role in particular value chains, by concentrating companies and economic flows related to these chains. The way this organization will take place spatially, i.e., which cities are important for each value chain and which level of importance (national, regional, or global) is related to many factors, such as the characteristics of the chain itself and its organization.

Considering these issues, the present work seeks to identify the cities that are the primary investment origin of the oil and gas investment network; to understand why they hold this position, in other words, what are the attributes that make them the main origin of investments in oil and gas in the region; and the spatial extent of such centrality (regional or national).

Several studies on the organization of value chains have been carried out. However, most of them (Peppard \& Rylander, 2006; Fernandez-Stark et al., 2011; Sturgeon et al., 2008; Soosay et al., 2012), develop case-study analysis, focusing on the relationships between the different companies involved in value chains. This study seeks to contribute by incorporating network methodology in the value chain analysis and more strongly including the spatial dimension of value chains' organization and the centrality asymmetries existing between different places.

For this purpose, we drew networks from data on the flows of foreign direct investment (FDI) and mergers and acquisitions (M\&A) in the oil and gas chain from 2006 to 2015. We analysed these flows according to the nodes' 
outdegree and to Louvain communities. The application of Louvain communities represents a significant methodological contribution of this paper, because to date this method has been widely used in the natural sciences but not in the social sciences (Hidalgo, 2016; Martinus \& Sigler, 2017).

In addition to this introduction and the conclusion, the present work includes three more sections. In the first section, a bibliographical review is carried out of authors and concepts that guide our analysis. This section also summarizes the activities that make up the oil and gas chain. Section 2 discusses in more detail the methodology applied in the study, and Section 3 presents the results of our analysis.

\section{Theoretical discussion}

\subsection{The new organization of the world economy}

The increasing deregulation of markets and the global credit system, as well as the increasing globalization of production and financial flows, have given rise to a new pattern of spatial organization. The greater mobility of capital has implied a reallocation of activities, with industries going to peripheral countries, searching, initially, for cheaper labour (Brenner, 1998). With this movement, the geographic organization of production underwent significant changes (Sassen, 1991).

This reorganization also affected the economies in the global South. With the new format of production and enhanced pressure for an economic opening, countries such as China, India, and Brazil became increasingly integrated into the global economy. As a result, production chains became more and more internationalized, concentrating some productive steps on these new players, which offered advantages such as cheap labour, abundant raw materials, and large domestic markets (Gereffi, 2013). Hence, new locations, including in the global South, have become increasingly important in capital flows.

Although this movement of dispersion and productive fragmentation into chains has intensified over time, administrative activities are still centralized in some large cities, which, as a consequence, concentrate many of the global economic flows (Sassen, 1991; Friedmann, 1986; Friedmann \& Wolff, 1982). According to Sassen (1991), this concentration of flows is due 
not only to the fact that certain cities are home to transnational corporations, but also because they are centres for financial and support activities.

Sassen (1991) considers that the extent to which cities will play the role of economic activity concentrators varies, as some play such a role at the global level and others at the regional and national levels. Whilst Sassen mentions it, she did not explore the regional and national roles of the cities in her work. Other authors have stressed this point, such as Martinus et al. (2015). They affirm that many cities play an important role in regionally developed chains, but this role is not widely explored in the literature.

In spite of the fact that there is a growing geographic dispersion and global integration in economic activities, because different stages of the same productive chain take place in different locations throughout the globe, Sassen (1991) states that there is a continuous concentration of economic control and ownership. This concentration is one more aspect that contributes to the central role played by some cities.

The concentration of control and ownership is directly related to the configuration assumed by value chains, because, although the productive process is experiencing fragmentation both geographically and along the chain itself, the relationships developed within value chains are not egalitarian, as some agents may hold more power than others. Which company occupies the leader position and how it develops its relations with the subordinate companies within the chain becomes, then, especially important. In this context, the power aspect gains more prominence. About this, in his early works, Gereffi (2001) claims there are two types of chains: producer-driven and buyer-driven.

Producer-driven chains have as a main characteristic the fact that they have large producers in the central role of the productive network coordination; this is more common in capital-intensive industries such as those for automobiles, computers, and machinery. Buyer-driven chains are characteristic of industries where large retail chains play a major role in establishing decentralized production in many countries, typically in developing countries. This pattern of trade-led industrialization is common in labour-intensive sectors, such as footwear and toys (Gereffi, 2001).

This classification has been guiding several works in the area. According to Carballa et al. (2014), these works focus on three essential branches: 1. how the exchanges happen between companies in different stages of the chain; 2. which actors within the chain can define the coordination 
process; and 3. the consequences of this coordination for the participants in the chain, regarding risk distribution and profits.

These three points do not allow the understanding of the spatial hierarchy outcomes related to the distribution of value chains and power asymmetries within them (Mahutga, 2014; Ravenhill, 2014). However, according to Dicken et al. (2001), the issue of power asymmetry is central to the understanding of the global economy and the new interconnected dynamics that have been developed. Dicken et al. (2001) consider that flows of diverse natures constitute the global economy. Thus, it is important to focus on the centrality and the way the different actors exercise power. The network methodology enables this analysis.

Several authors, such as Powell (1990) and Kirman (1997), have already applied the network framework to investigate the dynamics of the global economy. This analysis starts from the idea that the network's design reflects a set of relational processes that produce observable patterns in the economy. Therefore, the network framework requires the identification of actors, their relationships, and the structural results of these relationships.

For Dicken et al. (2001), power and centrality within the global economy networks are not related to specific actions, but mostly to the control of resources that some agents hold. For the authors, the role that a node plays in the network is derived not only from the position that the agents occupy but also from the control they have over strategic resources, be they physical, political, economic, or technological.

The authors also point out that networks have specific territoriality and organization, which is understood as a result of the activities being analysed. For example, some networks of global scope are controlled by actors spatially distant from where the activities occur, which is the case when the relations between the financial market and the industry are analysed (Dicken et al., 2001).

From this, we can conclude that the networks' territoriality is directly linked to the type of economic activity studied and to the specific characteristics of this activity. Therefore, the networks' territoriality is shaped by the agents participating in the network and the relationships developed among them. This point relates to the work of some authors, who argue that the spatial analysis that involves the identification of important cities for world economic flows have to be carried out in sectoral approaches, because many cities are important for certain sectors but not for others. 
Thus, an aggregated analysis would not allow the visualization of spatial organization specificities (Martinus \& Tonts, 2015; Krätke, 2014; Wall \& van der Knaap, 2011).

Martinus and Sigler (2017) adopted the method of networks and identification of communities in a work that addressed the specific dynamics of different industries and their spatial organization. The authors concluded that this is an important way to contextualize cities within the economic dynamics of certain sectors and is more appropriate than other methodologies that also address the role of cities in the global economy. However, this methodological resource has not yet been widely explored in the social sciences.

\subsection{The oil and gas value chain}

Knowing the oil and gas value chain is fundamental to understand its spatial organization. This value chain is characterized by a set of activities linking exploration and production (upstream) of oil and gas wells; transportation, refining, and distribution (midstream stage); and the transformation of its derivatives by the petrochemical industry (downstream stage) (Valente, 2009; Ruas, 2012; Oliveira, 2016).

The oil and gas industry is capital intensive and is made up of large groups that are among the largest companies in the world. These large groups are intensely verticalized, with the existence of highly integrated groups. They occupy a prominent position in the coordination of this chain, which characterizes it as producer driven. Different countries occupy the positions of large producers and large consumers, and this has structured the market, through intensive flows of international trade, with companies operating in several parts of the world (Ruas, 2012).

Besides the large oil groups, this chain is composed of companies that perform more specialized activities, focused on particular segments. These companies are responsible for offering specialized services and equipment to support the activities of the oil and gas chain (Ruas, 2012).

According to Ruas (2012), the service providers and suppliers are very heterogeneous, ranging from integrated and internationalized companies to specialized regional ones. These companies operate in the upstream stage, in exploration and production (E\&P) projects headed by large oil 
companies, performing activities such as reservoir information, drilling, completion, production, maintenance, and logistics.

The oil and gas value chain starts with the identification of sites with potential for exploration. Because in most countries the state has jurisdiction over the subsoil, this defines the terms under which exploration will take place, and the oil companies must acquire the exploration rights. After this acquisition, seismic surveys and drilling will be carried out, and if oil or gas is discovered, the field will be delimited and characterized, regarding extension and production possibility. After this stage, the infrastructure will be built to enable production (Oliveira, 2016).

In the drilling and completion stages, a significant portion of the expenditures required in an E\&P project occurs. These activities are heavily concentrated, with few companies accounting for a large market share. These companies stand out for high investments in research and development ( $R \& D)$, which constitutes a strong barrier to entry in this segment. Additionally, in drilling, capital requirements to acquire equipment are also barriers to entry. This stage is characterized by the operation of large groups, rather than specialized companies, as in the completion. The equipment used in this stage is built by specialized suppliers and shipyards, in the case of offshore exploration (Oliveira, 2016).

After the field production of oil, it will go to refineries, where fuels and inputs for the chemical industry are produced. Refineries are usually owned by large oil companies, which operate upstream and in distribution, evidencing the strong integration of these companies (Oliveira, 2016).

\section{Methodology}

Guided by the objectives of the present study, we combined different network measures, with a qualitative analysis of the prominent cities in the network. The central idea guiding the methodology framework is the statement by Dicken et al. (2001) that the analysis of the global economy involves an understanding of who the most powerful actors are; the control over what resources make them powerful; and how they exercise this power. We understand power here as having greater centrality in the network, and the exercise of power is explained here at a spatial level. Hence, we conduct the research in three steps: 
1) network design and centrality measurement, to identify the nodes with greater outdegree centrality in the network;

2) qualitative analysis of which resources contribute to the position occupied by the central nodes; and

3) identification of the extent of nodes' spatial centrality, through the formation of communities.

A network consists of nodes and links that form a pattern of connections, where nodes are actors and connections are relations (Taylor, 2001; Jackson, 2009). For the design of the networks analysed in the present study, data were collected from the fDi (2016) and Zephyr (2016) databases on FDI and M\&A projects from 2006 to 2015. We chose a long-term time cut with the objective of capturing the dynamics of the sector completely, eliminating the risk of bias by a short temporal cut, which may involve extraordinary events. We will investigate all the flows in databases that originate with and are destined to a location in South America.

The option to use FDI and M\&A flows to analyse the centrality of different localities has to do with the fact that, as stated by Bathelt and Fei Li (2014), such investment relations are the basis for the realization of diverse other flows (material, human capital, knowledge, technology), establishing intense and long-term relationships among several localities. Thus, we understand that the localities with more centrality, that is, the ones that are the origin of more investments, establish more channels for flows with other localities, having a greater relational capacity. We also understand that the fact that a location is the origin of the investment puts it in a powerful position, as it has control over the investment project. Thus, we adopt the outdegree as the main measure to identify the most important cities.

FDI Markets comprises data on greenfield FDI, that is, only international flows are present in this database. The Zephyr database comprises data on M\&A, that is, brownfield investments. In this database, both inter- and intranational flows are present, as its focus is not strictly on FDI, as in FDI Markets. In summary, the data from FDI Markets shows only international flows, and the Zephyr data show both inter- and intranational flows.

As the objective of this work is to identify the cities with greater centrality in the network, and due to the insufficient information at the city level for all the existing flows, we decided to define the origin of the investment at the city level and the destination at the country level. Thus, we generated a two-mode network. This practice does not affect the an- 
alytical purposes of the work and favours the analysis by allowing the inclusion of $100 \%$ of flows available in the databases, since many FDI and M\&A projects show the city of origin but do not provide information about the city of destination. This happens because the place where the investment takes place is often the site of exploration of an oilfield, which is not necessarily located in a city but always belongs to a country, for which information is always available. Also, many M\&A flows occur within the same city, and using the city as the origin and the country as the destination enables the capturing of these flows, which would not be possible if only the cities were used as origin and destination.

To trace the connections, we used the absolute number of projects, as in Crescenzi et al. (2016), who state that using the number of projects, instead of the value invested, is more suitable when we are looking at location strategies, because the choice to invest in a certain place is "largely independent from the amount invested" (p. 7).

After the network design, some analysis will be carried out based on the centrality measures of this network, mainly the outdegree. The outdegree, that is, the number of arcs that originate in a node, is calculated according to equation 1 :

$$
O D(i)=\sum_{j=1}^{N} W(j, i)
$$

where $i$ and $j$ are nodes of the network and $W(j, i)$ is the weight of the connection between $i$ and $j$ in the adjacency matrix that forms the network (Margarido et al., 2008).

In sequence, in order to understand the nature of the main cities position, a qualitative analysis will be carried out. We develop this qualitative analysis using bibliographical review, three interviews with oil and gas companies, official documents related to the oil and gas chain, and consultation of other databases, such as "A barrel full", a database that shows data on oil and gas fields and their respective operating companies.

Finally, we investigate the spatial extent of the central cities. For this, we apply the community grouping method proposed by Blondel et al. (2008), called the Louvain method. This approach also implies a methodological advance, because, to date, few studies have focused on city-level analysis and the social sciences have applied communities partitioning (Martinus \& Sigler, 2017). 
This method is based on the modularity maximization, defined according to equation 2 :

$$
Q=\frac{1}{2 M} \sum_{I, J}\left[A_{i, j}-\frac{k_{i} k_{j}}{2 m}\right] \delta\left(c_{i}, c_{j}\right)
$$

where $A$ is the sum of the weights of the vertices $i, c$ is the community where $i$ is inserted, the function $\delta(u, v)$ is 1 if $u=V$ and 0 if $u \neq v$, and $m=1 / 2 \Sigma A$. The technique used to identify communities in the Louvain method is based on two stages:

1) Each node is assigned to a community in order to maximize the $Q$ modularity of the network. The gain obtained from the allocation of a node $i$ to a community $c$ can be calculated as shown in equation 3 :

$$
\Delta Q=\frac{\sum_{c}+k_{i}^{C}}{2 m}-\left(\frac{\sum_{i}+k_{i}^{C}}{2 m}\right)^{2}-\left[\frac{\sum_{c}}{2 m}-\left(\frac{\sum_{i}}{2 m}\right)^{2}-\left(\frac{k_{i}}{2 m}\right)\right]
$$

where $\Sigma c$ is the sum of the weights of the arcs incident on $c, k$ is the sum of the weights incident on node $i, k_{i}^{c}$ is the sum of the weights of the arcs from $i$ to the nodes in $c$, and $m$ is the sum of the weights of all nodes in the network.

2) The second stage is the elaboration of a new network with the nodes belonging to each community. Then the process repeats itself until there is a significant improvement in network modularity.

\section{Results and discussion}

\subsection{The oil and gas investment network in South America}

Figure 1 shows the network outlined from the FDI and M\&A flows. The locations that appear in orange are in South America, while the ones in green are from outside the region.

The most notable features of this network are the concentration of connections in a few nodes, and the existence of many small nodes with limited participation in the investment flows. This characterizes a scale-free network, according to Barabási (2009), which means that the 
network does not have a representative node, but rather that there is a hierarchy with large connectors, medium connectors, and nodes with few connections.

Figure 1 Oil and gas investments network in South America

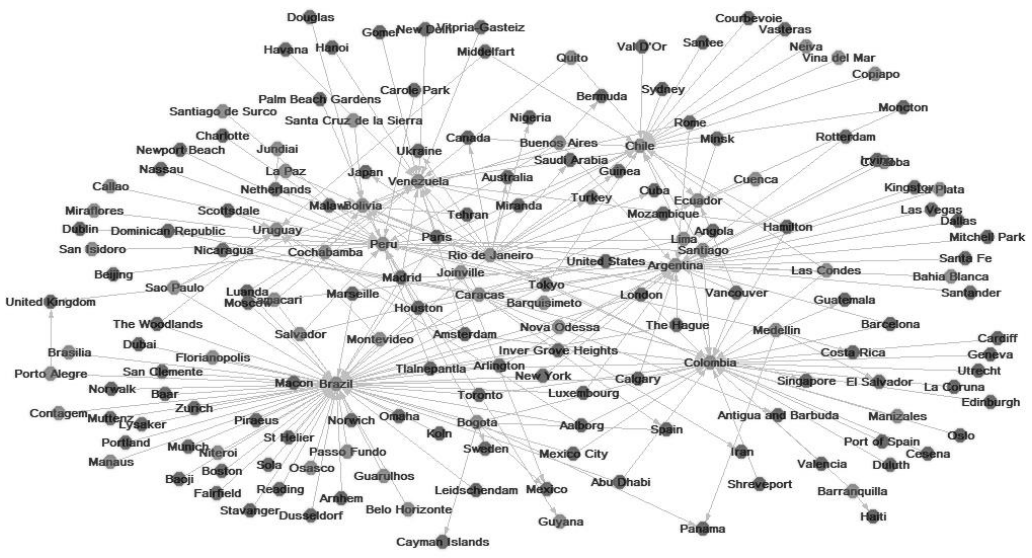

Source: Author's draft based on fDi Markets, a service from fDi (2016) and Zephyr (2016).

The visual analysis of the figure allows the verification that Rio de Janeiro is the main origin for investments in the oil and gas chain in South America and that Brazil is the primary destination. To show in more detail the role performed by some localities, Table 1 shows the outdegree of the network in Figure 1.

Table 1 Network Outdegree

\begin{tabular}{lr}
\hline Rio de Janeiro & 63 \\
\hline São Paulo & 31 \\
\hline Bogota & 26 \\
\hline Buenos Aires & 26 \\
\hline Caracas & 22 \\
\hline Calgary & 20 \\
\hline Madrid & 17 \\
\hline Medellin & 13 \\
\hline
\end{tabular}

Source: Author's draft. 
The outdegree values in Table 1 evidence that South American cities play an important role within the regional network. Of the top eight cities, only two are from outside the region: Calgary and Madrid. Another important aspect is the dominance of Rio de Janeiro as the main origin for investments. Rio de Janeiro was the source of 63 investments, twice the number for São Paulo, the second largest city regarding investment origin, which is followed closely by Bogota.

\subsection{Understanding Rio de Janeiro's centrality}

Rio de Janeiro's centrality confers a powerful position for the city within the network, because it is the isolated leader in the origin of oil and gas investments in the region. In this way, the number of channels for other flows established between this city and other locations in the network is the highest one. Hence, Rio de Janeiro is classified as a strong connector within this network (Barabási, 2009). As this section shows, its connectivity derives mainly from its role in the upstream stage of the chain.

We explain the city's position within the network based on the perspective of Dicken et al. (2001), that is, we stress the resources that the city holds, which contribute to its centrality within the network and make it a strong connector.

One of the factors that explain Rio de Janeiro's centrality is that this city hosts the headquarters of Petrobras. Although since 1997 Petrobras has no longer held a monopoly over oil and gas activities in Brazil, it is still responsible for the exploration of a large part of the national oilfields and produces almost $90 \%$ of the oil in Brazil (ANP, 2016). The role of Petrobras within the network of investment flows in oil and gas in South America is seen in Table 2, which shows the main investing companies in the network. The company is the largest oil company in South America, according to a ranking released by Platts consulting firm, which evaluates criteria such as asset value, revenue, profit, and return on capital. The company has occupied this position from 2002, when the ranking was created, to 2015, when Colombian Ecopetrol took its place (Exame magazine, available at http://exame.abril.com.br/negocios/petrobras-perde-o-posto-demaior-da-america-do-sul-veja-o-ranking). 
Table 2 Leading investment companies in the South American oil and gas chain

\begin{tabular}{lrrrr}
\hline Company & $\begin{array}{r}\text { No. of FDI and } \\
\text { M\&A entries }\end{array}$ & Headquarters & Main activity \\
\hline Petrobras & 38 & Rio de Janeiro & E\&P \\
\hline PDVSA & 25 & Caracas & E\&P \\
\hline Repsol & 11 & Madrid & E\&P \\
\hline Ultrapar & 10 & São Paulo & $\begin{array}{r}\text { Distribution/chemical } \\
\text { specialties }\end{array}$ \\
\hline Braskem & 10 & São Paulo & Petrochemicals \\
\hline
\end{tabular}

Source: Authors' own calculations based on fDi Markets, a service from fDi (2016) and Zephyr (2016).

Table 2 shows that within the South American FDI and M\&A flows, Petrobras is the company with the largest participation, with a $50 \%$ greater number of entries, compared to second-placed Venezuelan PDVSA. We also note that the top three companies by the number of entries are large oil companies. As already mentioned, the oil chain is producer driven. Thus, large and integrated oil companies play a central role in this network.

Petrobras operates in several parts of the globe, including Africa, America, Asia, and Europe, in different chain stages (Costa \& Pessali, 2009). However, there is still a more intense performance in South America. In 2015, almost $47 \%$ of the proven foreign reserves of Petrobras were there. The company operates in different areas in many countries. In Chile, Paraguay, and Uruguay it operates within trade and distribution, being the leader in the sector. In Peru and Bolivia it has an exploration business, and in the latter Petrobras also operates in production and transportation by pipelines. In Venezuela and Colombia, there are partnerships in the distribution sector. This segment is also present in Chile, where there are 279 posts; in Argentina, with 265 posts; in Paraguay, with 180 posts; and in Uruguay, with 87 posts. The market share of the company in each of these countries is $12.5 \%, 6.1 \%, 19.5 \%$, and $22.7 \%$, respectively (Petrobras, 2015).

Besides Petrobras, private oil companies are also present in Rio de Janeiro. According to a 2016 report by the ANP (National Petroleum Agency), of the $104 \mathrm{E} \& \mathrm{P}$ concessionaires operating in the Brazilian oil wells, 65 of them were based in Rio de Janeiro, and several of these companies are multinational. According to Costa and Pessali (2009), since the bidding system for the concession of exploration blocks was instituted by ANP in 1999, Petrobras has participated actively, and foreign companies often 
participate in partnership with it. This close relationship that many foreign companies have developed with Petrobras - since the liberalization of the Brazilian national oil sector-has motivated their establishment in Rio de Janeiro to explore the advantages of geographical and institutional proximity (Boschma, 2005).

It is worth noting that Rio de Janeiro is not the only city in South America that hosts multinational oil and gas companies' headquarters. These companies are more or less concentrated in several cities, reflecting the decentralization of this sector, which is strongly influenced by the regulatory framework and countries' national energy security agendas (Martinus \& Sigler, 2017).

In addition to large oil companies, the oil and gas chain is also composed of specialized service providers and suppliers. These companies are also strongly concentrated in Rio de Janeiro. Through research on the location of the enterprises operating in South American oil and gas fields, information collected in the A barrel full database, and information on the companies' websites, it was possible to verify that Rio de Janeiro is the main location in South America for these companies, as shown in Table 3.

Table 3 Number of specialized service providers' and suppliers' offices in South American cities

\begin{tabular}{lr}
\hline City & Number of enterprises \\
\hline Rio de Janeiro (BRA) & 18 \\
\hline Bogota (COL) & 7 \\
\hline Lima (PER) & 7 \\
\hline Caracas (VEN) & 4 \\
\hline Santiago (CHI) & 4 \\
\hline Macaé (BRA) & 3 \\
\hline Buenos Aires (ARG) & 2 \\
\hline São Paulo (BRA) & 2 \\
\hline Santa Cruz de la Sierra (BOL) & 2 \\
\hline
\end{tabular}

Source: Author's draft based on the companies' websites.

Table 3 shows the office locations of a sample composed of 47 companies operating in the South American oilfields. These data show how these companies are strongly concentrated in Rio de Janeiro, with more than twice as many offices as the second highest city. 
The concentration of specialized service providers and suppliers in Rio de Janeiro reflects the size of the Brazilian market. According to a report released by the International Energy Agency in 2013, Brazil owned 21\% of the floating, storage, and offloading units and 37\% of the "wet Christmas trees," which are essential pieces of equipment for offshore exploration. Thus, Brazil is one of the main markets for this equipment. Hence, companies that operate in this segment will have a special interest in being close to Petrobras, which is the main Brazilian customer (Oliveira, 2016).

According to an interview conducted in 2017 with an international service provider installed in Rio de Janeiro, the company's subsea activities are concentrated in the Rio de Janeiro office, serving not only Petrobras but also foreign companies such as BP and Chevron. This information shows Rio de Janeiro's importance as an oil and gas centre, mainly in the subsea segment.

In addition to having a large concentration of companies, Rio de Janeiro is also the centre for significant research efforts in the area. First, there is the Cenpes (Research and Development Center "Leopoldo A. Miguel de Mello"), the Petrobras research centre at the Federal University of Rio de Janeiro (UFRJ). This centre, which is the company's main research institution but not its only one, was fundamental in the development of deepwater drilling technologies, which guaranteed technological leadership in this area to Petrobras (Neto \& Costa, 2007; Costa \& Pessali 2009; Lima \& Silva, 2012).

Moreover, some R\&D centres of transnational companies involved in the oil and gas upstream stage are also installed in Rio de Janeiro. Data presented in Piquet et al. (2016) show that, of the 18 new oil and gas R\&D centres that have been installed in Brazil in the last 10 years, 15 are located in the city, with the majority of these centres located in an area owned by UFRJ. Among the companies that installed R\&D centres in the city are Baker Hughes, FMC Corporation, and Vallourec, companies with important roles in the South American oil and gas network and that are among the world leaders in the segments in which they operate.

The installation of these $R \& D$ centres of transnational companies in Rio de Janeiro is motivated, among other factors, by the discovery of the pre-salt layer in 2007, coming from sedimentary basins which go from the coast of Espirito Santo to São Paulo (Pedrosa \& Corrêa, 2016). The exploration of the layer requires new technologies and logistical solutions (Piquet, 2016). Therefore, the demand for new technologies and solutions 
and the significance of the pre-salt as a new deposit with great productive potential have stimulated foreign investment in R\&D (Piquet, 2016).

R\&D activities performed by foreign companies in Rio de Janeiro, and in Brazil in general, are also due to legislation regarding the sector, which, since 2005 , has determined that $1 \%$ of the total gross production of highly productive fields should be invested in R\&D. A part of this $1 \%$ can be applied in the enterprises' own R\&D centres or in Cenpes, and another part must be applied in non-profit institutions, such as universities and public research institutes (Oliveira, 2016; Tordo et al., 2013).

Thus, Rio de Janeiro is a centre of the oil and gas chain upstream stage. This centrality is materialized in the concentration of the origin of the FDI and M\&A flows in the South American network in that city. This concentration is explained in large part by the presence of Petrobras, which holds a leading role in the region. The fact that Rio de Janeiro hosts the company's headquarters motivates other companies, which seek to operate in partnership with Petrobras to settle in Rio de Janeiro. An interviewee confirmed this information.

\subsection{Subnetworks formation}

The data presented on the oil and gas investment flows show the centrality of Rio de Janeiro. However, Figure 1 does not allow the visualization of the real extent of the city's role or the spatial extent of this role. Although Rio de Janeiro stands out as a source of investments in the oil and gas chain, does this centrality extend to the regional context, or is it focused at the national level ${ }^{1}$ ? We applied community analysis to answer this question. The communities show the spatial extent role of the cities that concentrate the flows through the formation of the subnetworks. These subnetworks are shown in Figure 2.

Initially, we can see that Brazil's community is the one with the largest number of cities. This evidences the importance that the country holds as a pole of investment attraction in the oil and gas chain.

By grouping the most connected nodes, community analysis allows us to see the strong national scope of investment flows in South America. In 1 It is worth noting that FDI flows are essentially international, but M\&A flows can be both international or intranational. 
almost all communities there are one or two South American countries, and in the same community to which these countries have been assigned, there are also a large number of cities from the same country.

\section{Figure 2 Louvain communities in the network of FDI and M\&A flows in oil and gas in}

\section{South America}

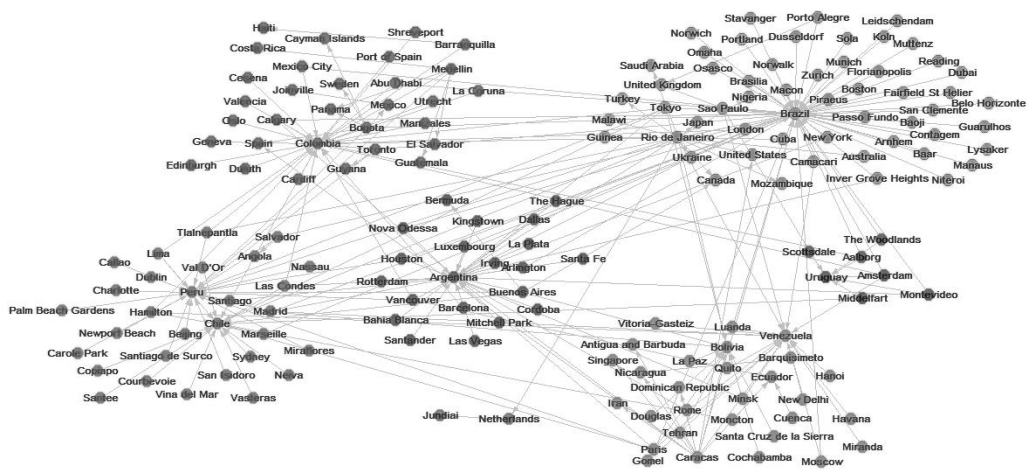

Source: Author's own draft based on fDi Markets, a service from fDi (2016) and Zephyr (2016).

This is clear when we look at the community in which Brazil is inserted. São Paulo and Rio de Janeiro are also in this community, as are several other Brazilian cities. Only a minority of Brazilian cities are in different communities. This pattern is the same if we observe the communities of Argentina, Colombia, and other countries.

In this way, we conclude that although it is a prominent city within the South American network, Rio de Janeiro's sourced investments are focused on Brazil, with little echo in the region as a whole. This is the general trend of flows in this chain, because all the communities have similar patterns.

This result is in agreement with results shown in other studies that also dealt with the energy sector and evidenced that the institutional specificities of the different producing countries contribute to the decentralization of the chain flows at a global level and concentration at the national level. Martinus and Sigler (2017) showed the strong decentralization of the organization of the energy sector in general. Breul and Revilla Diez (2017) also identified a strong concentration at the national level of the organization of E\&P companies in Southeast Asia. 


\section{Concluding remarks}

This study aimed to analyse the spatial organization of the oil and gas chain in South America, based on the FDI and M\&A flows in the region. These flows were analysed using a mixed-approach methodology, combining networks and Louvain communities with a qualitative approach. In this way, we sought to contribute to the literature of value chains, bringing a spatial analysis with a focus on cities, and a methodology not widely applied in the studies in the area until now.

Based on the analysis, we verified the strong centrality of Rio de Janeiro in the investment flows of the region, which is by far the main source city of investments. This centrality puts the city in a powerful position in the South American network and is due, in the sense used by Dicken et al. (2001), to the resources the city holds.

One of Rio de Janeiro's central attributes is the fact that it hosts Petrobras. Because this chain is characterized as a producer-driven one, the large oil companies exert control over the chain activities. In addition to being the largest oil company in South America, Petrobras is an important player in the deep-water offshore exploration segment, being one of the technological leaders in this segment. Besides, the company operates throughout all of South America, in several stages, from exploration to distribution. Aiming at having proximity to Petrobras, many private oil companies, specialized service providers, and suppliers are also located in Rio de Janeiro.

Besides hosting major upstream companies, Rio de Janeiro also hosts several oil and gas research centres. In addition to Cenpes, of Petrobras, several privately owned companies also have R\&D centres in the city. Therefore, apart from being an important centre of companies in the segment, Rio de Janeiro is also characterized as an important centre for knowledge and technology production. Regarding this issue, the state plays an important role, because the regulatory framework encourages the installation of R\&D facilities.

Through community partitioning it was possible to verify that the scope of this centrality is mainly national, although Rio de Janeiro's centrality in the South America investment network is remarkable. This result is in agreement with other studies that have already discussed the strong national centralization of the oil and gas chain. This is mainly because this chain is strongly influenced by local politics and the institutional environ- 
ment, factors that shape the terms in which the production of the sector will be carried out.

Although the prominence of Rio de Janeiro as the centre of the oil and gas chain in the South America network is evident, the crisis in the Brazilian sector and in Brazilian politics was not widely grasped through the analysis we developed, as our data on FDI and M\&A flows are applicable only until 2015. This initial analysis opens a new research path to investigate whether there has been a change in the role of Rio de Janeiro in this specific network, and if so, investigating the nature of this change.

\section{References}

ANP (Agência Nacional do Petróelo). Anuário Estatístico. 2016. Available at: http://www. anp.gov.br/wwwanp/images/publicacoes/Anuario_Estatistico_ANP_2016.pdf.

BARABÁSI, A. L. Linked: a nova ciência dos networks. São Paulo: Leopardo, 131, 2009.

BATHELT, H.; FEI LI, P. Global cluster networks-foreign direct investment flows from Canada to China. Journal of Economic Geography, v. 14, n. 1, p. 45-71, 2014.

BLONDEL, V. D. et al. Fast unfolding of communities in large networks. Journal of Statistical Mechanics: Theory and Experiment, n.10, p. 1008-1020, 2008.

BOSCHMA, R. Proximity and innovation: A critical assessment. Regional Studies, v. 39, n. 1, p. 61-74, 2005.

BRENNER, N. Global cities, glocal states: Global city formation and state territorial restructuring in contemporary Europe. Review of International Political Economy, v. 5, n. 1, p. 1-37, 1998.

BREUL, M.; REVILLA DIEZ, J. Städte als regionale Knotenpunkte in globalen Wertschöpfungsketten: das Beispiel der Erdöl-und Erdgasindustrie in Südostasien. Zeitschrift für Wirtschaftsgeographie, 2017.

CARBALLA, B. et al. Uneven development patterns in global value chains. CEPN Working Papers from HAL, 2014.

COSTA, A.; PESSALI, H. F. A trajetória de internacionalização da Petrobras na indústria de petróleo e derivados. História Econômica \& História de Empresas, v. 12, p. 5-31, 2009.

CRESCENZI, R. et al. European cities and foreign investment networks. Papers in Evolutionary Economic Geography, v. 16, n. 16, p. 229-260, 2016.

DICKEN, P. et al. Chains and networks, territories and scales: Towards a relational framework for analysing the global economy. Global Networks, v. 1, n. 2, p. 89-112, 2001.

EXAME MAGAZINE. Petrobras perde o posto de maior da America do Sul. 2016. Available in http://exame.abril.com.br/negocios/petrobras-perde-o-posto-de-maior-da-america-do-sul-veja-o-ranking/ 
FDI MARKETS DATABASE. The Financial Times, 2016.

FERNANDEZ-STARK. et al. The offshore services global value chain. Skills for Upgrading, v. 132, p. 271-275, 2011.

FRIEDMANN, J. The world city hypothesis. Development and Change, v. 17, n. 1, p. 69-83, 1986.

FRIEDMANN, J.; WOLFF, G. World city formation: an agenda for research and action. International journal of urban and regional research, v. 6, n. 3, p. 309-344, 1982.

GEREFFI, G. Beyond the producer $\bigotimes$ driven/buyer冈driven dichotomy: The evolution of global value chains in the internet era. IDS Bulletin, v. 32, n. 3, p. 30-40, 2001.

GEREFFI, G. Global value chains in a post-Washington Consensus world. Review of International Political Economy, v. 21, n. 1, p. 9-37, 2013.

HIDALGO, C. A. Disconnected, fragmented, or united? A trans-disciplinary review of network science. Applied Network Science, v. 1, n. 1, p. 6, 2016.

JACKSON, M. O. Social and economic networks. Princeton, NJ: Princeton University Press, 2009.

KIRMAN, A. The economy as an evolving network. Journal of evolutionary economics, v. 7 , n. 4, p. 339-353, 1997.

KRÄTKE. Global pharmaceutical and biotechnology firms' linkages in the world city network. Urban Studies, v. 51, n. 6, p. 1196-1213, 2014.

LIMA, M. F. D. C.; SILVA, M. A. Inovação em petróleo e gás no Brasil: A parceria Cenpes-Petrobras e Coppe-UFRJ. Sociedade e Estado, v. 27, n. 1, p. 97-115, 2012.

MAHUTGA, M. C. Global models of networked organization: The positional power of nations and economic development. Review of International Political Economy, v. 21, n. 1, p. 157-194, 2014.

MARGARIDO, P. R. et al. Estabilização de métricas de redes complexas. In: Anais do XXVIII Congresso da SBC, 2008, Belém. Anais... Belém, 2008, p. 61-70.

MARTINUS, K. et al. Strategic globalizing centers and sub-network geometries: A social network analysis of multi-scalar energy networks. Geoforum, v. 64, p. 78-89, 2015.

MARTINUS, K.; SIGLER, T. J. Global city clusters: Theorizing spatial and non-spatial proximity in inter-urban firm networks. Regional Studies, v. 52, n. 8, p. 1-13, 2017.

MARTINUS, K.; TONTS, M. Powering the world city system: Energy industry networks and interurban connectivity. Environment and Planning A, v. 47, n. 7, p. 1502-1520, 2015.

NETO, J. B. O.; COSTA, A. J. D. A Petrobrás e a exploração de Petróleo Offshore no Brasil: Um approach evolucionário. Revista Brasileira de Economia, v. 61, n. 1, p. 95-109, 2007.

POWELL, W. Neither market nor hierarchy. The Sociology of Organizations: Classic, Contemporary, and Critical Readings, v. 315, p. 104-117, 1990.

OLIVEIRA, R. L. Resource-led Industrial development in the oil \& gas supply chain: The case of Brazil. MIT Industrial Performance Center Working Paper Series, 2016.

PEDROSA JR., O. A.; CORRÊA, A. C. F. A crise do petróleo e os desafios do pré-sal. Boletim de Conjuntura, v. 2, p. 4-14, 2016.

PEPPARD, J.; RYLANDER, A. From value chain to value network: Insights for mobile opera- 
tors. European Management Journal, v. 24, n. 2, p. 128-141, 2006.

PETROBRAS. Fatos e Dados. 2015. Available in: http://www.petrobras.com.br/pt/?

PIQUET, R. P. et al. O desenvolvimento e a política de conteúdo local na indústria petrolífera: Visões divergentes. Revista Tecnologia e Sociedade, v. 12, n. 24, p. 45-58, 2016.

RAVENHILL, J. Global value chains and development. Review of International Political Economy, v. 21, n. 1, p. 264-274, 2014

RUAS, J. A. G. Dinâmica de concorrência na indústria parapetrolífera offshore: Evolução mundial do setor de equipamentos subsea e o caso brasileiro. Doctoral Dissertation, Institute of Economy/ UNICAMP, 2012.

SASSEN, Saskia. Global cities: New York, London, Tokyo. Princeton University Press. Princeton, 1991.

SOOSAY, C. et al. Sustainable value chain analysis: A case study of Oxford Landing from "vine to dine". Supply Chain Management: An International Journal, v. 17, n. 1, p. 68-77, 2012.

STURGEON, T. et al. Value chains, networks and clusters: Reframing the global automotive industry. Journal of Economic Geography, v. 8, n. 3, p. 297-321, 2008.

TAYLOR, P. J. Specification of the world city network. Geographical Analysis, v. 33, n. 2, p. 181-194, 2001.

TORDO, S. et al. Local content policies in the oil and gas sector. Washington, DC: World Bank, 2013.

VALENTE, F. S. P. F. A dinâmica da acumulação de capital e os movimentos de fusões e aquisições em estruturas de mercado oligopolísticas: Um estudo focado na evolução recente da indústria mundial do petróleo. Master's Dissertation, Institute of Economy/ UNICAMP, 2009 .

WALL, R. S.; VAN DER KNAAP, G. A. Sectoral differentiation and network structure within contemporary worldwide corporate networks. Economic Geography, v. 87, n. 3, p. 267-308, 2011.

ZEPHYR DATABASE COMPREHENSIVE M\&A DEALS AND RUMOURS WITH INTEGRATED COMPANY FINANCIALS. Bureau van Dijk, 2016.

\author{
About the authors \\ MarianeSantos Françoso - marisfrancoso@gmail.com \\ Universidade Estadual de Campinas, Campinas, São Paulo, Brasil. \\ ORCID: https://orcid.org/0000-0002-9785-3469. \\ MoritzBreul-moritz.breul@uni-koeln.de \\ University of Cologne, Cologne, Germany. \\ ORCID: https://orcid.org/0000-0002-0322-0987. \\ Celio Hiratuka - celiohiratuka@gmail.com \\ Universidade Estadual de Campinas, Campinas, São Paulo, Brasil. \\ ORCID: https://orcid.org/0000-0002-3265-3036.
}

This research was funded by FAPESP, grant n. 2016/06888-1.

\title{
About the article
}

Submission received on May 13, 2018. Approved for publication on December 12, 2018. 